\title{
Histology, ultrastructure and prevalence of Henneguya piaractus (Myxosporea) infecting the gills of Piaractus mesopotamicus (Characidae) cultivated in Brazil
}

\author{
E. A. Adriano ${ }^{1,2, *}$, S. Arana ${ }^{3}$, N. S. Cordeiro ${ }^{4}$ \\ ${ }^{1}$ Centro de Pesquisa e Gestão de Recursos Pesqueiros Continentais - CEPTA/IBAMA, Rod. SP 201, Km 6,5, Caixa Postal 64, \\ CEP 13630-970, Pirassununga, SP, Brazil \\ ${ }^{2}$ Centro Univeritário da Fundação de Ensino Octávio Bastos (UNIFEOB), Avenida Octávio da Silva Bastos, s/n, \\ Jardim Nova São João, CEP: 13870-000, São João da Boa Vista, SP, Brazil \\ ${ }^{3}$ Departamento de Histologia e Embriologia, and ${ }^{4}$ Departamento de Parasitologia, Instituto de Biologia, \\ Univertsidade Estadual de Campinas (UNICAMP), Caixa Postal 6109, CEP 13083-970, Campinas, SP, Brazil
}

\begin{abstract}
The histopathological and ultrastructural characteristics of Henneguya piaractus, a parasite of the gill lamellae of Piaractus mesopotamicus, are reported here. Histological analysis showed that the plasmodia were of the intralamellar type. The development of the plasmodia resulted in marked dilatation of the infected lamellae, with the neighbouring lamellae being displaced laterally. Discreet epithelial hyperplasia was observed, but there was no inflammatory reaction. Ultrastructural analysis showed that the plasmodium had a single thin wall that was in direct contact with the host cells. Pinocytic canals and points of phagocytosis were observed in the wall. The prevalence of the parasite varied according to host size, with the lowest prevalence occurring in hosts up to $10 \mathrm{~cm}$ long.
\end{abstract}

KEY WORDS: Myxozoa $\cdot$ Pacu $\cdot$ Histology $\cdot$ Ultrastructure $\cdot$ Lipid droplets $\cdot$ Prevalence

\section{INTRODUCTION}

Aquaculture is a rapidly developing activity in Brazil. Among the species being considered for fish farming, much interest has focused on Piaractus mesopotamicus (Holmberg, 1887), a large riverine fish commonly known as pacu. This interest is attributable primarily to the economic importance of this species, its adaptability to diverse culture conditions, its excellent food-to-growth conversion and its resistance to disease (Hernandez 1989). In this report, which is part of an ongoing investigation into the characteristics of myxosporean parasites of freshwater fish cultivated in Brazil, we describe the ultrastructural and histological characteristics of Henneguya piaractus Martins \& Souza, 1997, a parasite of pacu gills. In particular, the interactions between the plasmodium and adjacent cells, the spore characteristics, and the histopathological alterations were examined.

\section{MATERIALS AND METHODS}

Young specimens of 4 fish species: pacu Piaractus mesopotamicus (Characidae), curimbatá Prochilodus lineatus (Valenciennes, 1836) (Prochilodontidae), matrinxã Brycon cephalus (Gunther, 1869) (Characidae) and piauçu Leporinus macrocephalus, Garavello \& Britski, 1988 (Anostomidae), obtained from breeding facilities, were maintained together under fish farm conditions in a pond at the Center for the Research and Management of Continental Fishing Resources (CEPTA/IBAMA) in the municipality of Pirassununga, in the state of São Paulo, Brazil. The fish were monitored for 2 yr (March 2000 to February 2002), and each month 5 specimens of each species were examined for the presence of myxozoan parasites. Immediately after collection, the fish were transported alive to the laboratory, where they were killed by transection of the 
spinal cord before being measured and autopsied. Measurements were obtained from fresh mature spores using a micrometer incorporated into a microscope eyepiece and were expressed as the mean \pm standard deviation (SD). For histological analysis, parasitised gills were fixed in $10 \%$ buffered formalin for $24 \mathrm{~h}$, embedded in paraffin, cut into $4 \mu \mathrm{m}$ thick sections, and stained with haematoxylin and eosin and sirius red (Adriano et al. 2002). For ultrastructural analysis, fragments of gills containing plasmodia were fixed in $2.5 \%$ glutaraldeyde in cacodylate buffer $(2 \mathrm{~h})$, post-fixed in $1 \% \mathrm{OsO}_{4}(2 \mathrm{~h})$, dehydrated in increasing concentrations of acetone, and embedded in EponAraldite resin. Ultrathin sections double-stained with uranyl acetate and lead citrate were examined in a LEO 906 electron microscope operated at $60 \mathrm{kV}$.

The occurrence of the parasite throughout the year was examined by grouping the monthly samples according to the season of collection. The effect of season and host (fish) size on the prevalence of the parasite was assessed using the $\chi^{2}$ test, with the level of significance set at $\mathrm{p}<0.05$.

\section{RESULTS}

Of the fish species studied, only pacu were found to have the parasite. Of 120 pacu examined, 45 were 5 to $10 \mathrm{~cm}$ long, 41 were 10.1 to $20 \mathrm{~cm}$ long and 34 were 20.1 to $36 \mathrm{~cm}$ long. Fifty-four fish $(45 \%)$ had plasmodia of Henneguya piaractus in their gill lamellae. The plasmodia were polysporic, white, round or ellipsoidal, and measured $25 \mu \mathrm{m}$ (immature plasmodia) to $2.5 \mathrm{~mm}$ (mature plasmodia) in length. The measurements for fresh spores (Fig. 1) $(n=30)$ are shown in Table 1.

Histological analysis of infected gills of Piaractus mesopotamicus showed that the plasmodia were of the intralamellar type and occurred between the gill lamellar epithelium and the capillary (Figs. 2 to 4 ). The parasite caused stretching of the epithelium with accentuated deformation, as well as compression of the capillary and adjacent tissues (Fig. 3). The initial developmental stages of the parasite occurred in all regions of the gill lamellae (basal, medial and distal regions) (Figs. $2 \& 3$ ). In advanced stages, the plasmodia occupied the entire extent of the gill lamellae and produced marked dilatation and discreet epithelial hyperplasia. The extensive dilatation of infected lamellae caused displacement, deformation and eventually fusion of the neighbouring lamellae (Fig. 4). No inflammatory reaction was observed in the infected gills.

Ultrastructural analysis showed direct contact between the plasmodial wall and the host cells (Figs. 5 to 9). The plasmodial wall consisted of a single layer
Table 1. Henneguya piaractus. Measurements of fresh spores

\begin{tabular}{|c|c|}
\hline Parameter & Measurement \\
\hline Total length & $59.6 \pm 2.3 \mu \mathrm{m}$ \\
\hline Body length & $12.8 \pm 0.7 \mu \mathrm{m}$ \\
\hline Width & $4.1 \pm 0.2 \mu \mathrm{m}$ \\
\hline Length of caudal process & $46.4 \pm 2.1 \mu \mathrm{m}$ \\
\hline Polar capsule: Length & $6.5 \pm 0.4 \mu \mathrm{m}$ \\
\hline Width & $1.2 \pm 0.2 \mu \mathrm{m}$ \\
\hline No. of polar filament turns & $8-9$ \\
\hline
\end{tabular}

(Fig. 8) that was continuous with the pinocytic canals which extended into the thin, finely granular layer of the plasmodial ectoplasm (Fig. 7). In addition to the pinocytic canals, several phagocytes were seen engulfing parts of the host cells (Figs. $5 \& 7$ to 9).

The earliest stages of sporogenesis occurred at the periphery of the endoplasm, whereas mature spores were found in the central region (Figs. $5 \& 7$ ). The binucleate sporoplasm contained numerous lipid droplets, some dark sporoplasmosomes, ribosomes and randomly scattered rough endoplasmic reticulum (Figs. 10 $\& 12$ ). The polar capsules were elongated and consisted of a thin, dark outer wall, a less electron-dense inner layer, and a dark, granular central area containing the polar filament with its 8 to 9 coils (Fig. 11).

The prevalence of the parasite varied significantly with the season $\left(\chi^{2}=29.10, \mathrm{df}=7\right)$ (Fig. 13). The lowest prevalences occurred in the autumn and winter of 2000 (6.6 and $13.3 \%$, respectively), with no significant variation $\left(\chi^{2}=6.66, \mathrm{df}=5\right)$ between the spring of 2000 and the summer of 2001 (Fig. 13). The prevalence also varied significantly with host size $\left(\chi^{2}=25.24, \mathrm{df}=2\right)$. The lowest prevalence occurred in hosts up to $10 \mathrm{~cm}$ long, with no significant difference $\left(\chi^{2}=0.02, \mathrm{df}=1\right)$ between fish 10.1 to $20 \mathrm{~cm}$ long and those $>20 \mathrm{~cm}$ long (Fig. 14).

\section{DISCUSSION}

Although there was a significant difference in the prevalence between the seasons, this finding most likely reflects the time required for infection of the fish and the appearance of plasmodia after the initial contact with the host rather than true seasonal variation. In agreement with this conclusion, the lowest prevalence of the parasite occurred in the autumn and winter of 2000 (beginning of the study), with no significant variation in the subsequent seasons (spring 2000 to summer 2001). The prevalence also varied significantly with host size, with the lowest prevalence occurring in fish up to $10 \mathrm{~cm}$ long. When these smaller fish were excluded from the analysis, there was no significant variation in prevalence. The greater prevalence of the 

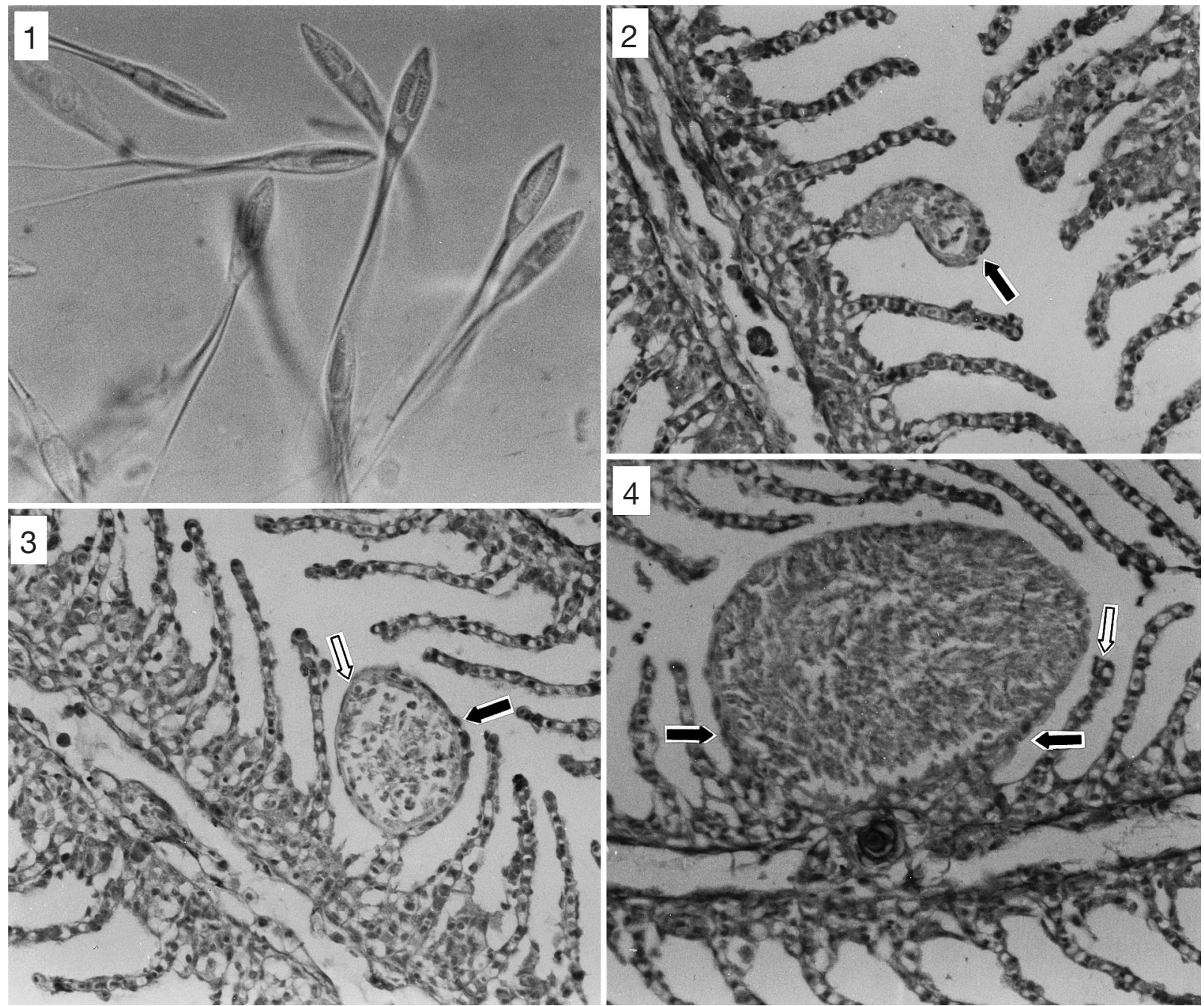

Figs. 1 to 4 . Henneguya piaractus. Light photomicrographs. Fig. 1 . Fresh mature spores $(\times 3600)$. Figs. 2 to 4 . Histological sections of gills of Piaractus mesopotamicus. Sirius red staining. Fig. 2. Immature plasmodium occupying the apical and median regions of the gill lamella (arrow) $(\times 1440)$. Fig. 3. Young plasmodium in the distal region of the gill lamella. Note the stretching and accentuated deformation of the epithelium (white arrow) and compression of the capillary and adjacent tissues (black arrow) $(\times 1360)$. Fig. 4. Mature plasmodium occupying the entire length of the gill lamella. Note the fusion of the nearest gill lamellae (black arrows) and the neighbouring lamellae pushed laterally (white arrow) $(\times 1120)$

parasite in larger fish was similar to that of other myxosporean species, such as Henneguya creplini infecting the gills of Stizostedion lucioperca (Molnár 1998) and Myxobolus muelleri and Myxobolus dujardini, parasites of Ptychochelus oregonensis, P. caurinus and Richardsonius blateatus (Mitchell 1988).

The specimens of Piaractus mesopotamicus examined were confined to a pond with 3 other fish species: Brycon cephalus (Characidae), Prochilodus lineatus (Prochilodontidae), and Leporinus macrocephalus (Anostomidae), but Henneguya piaractus was found only in pacu, indicating host specificity. Molnár (1998) suggested that Henneguya species may have a relatively strict host specificity. However, $H$. piaractus has been reported to infect pacu, tambaqui Colossoma macropomum, a large characid native to the Amazon river basin, and tambacu, a hybrid of these 2 species ( $P$. mesopotamicus male $\times C$. macropomum female), in a fish farm (Martins et al. 1999). This may indicate that $H$. piaractus has a host specificity restricted to closely related species-pacu and tambaqui are characids that can crossbreed with each other.

Ultrastructural analysis showed that sporogenesis in Henneguya piaractus followed the general pattern of other Henneguya species (Current 1979, Azevedo \& Matos 2002, 2003, El-Mansy \& Bashtar 2002, Vita et al. 2003). However, numerous spherical lipid droplets were immersed in the sporoplasm cells of $H$. piaractus. Similar lipid inclusions have also been reported in the 


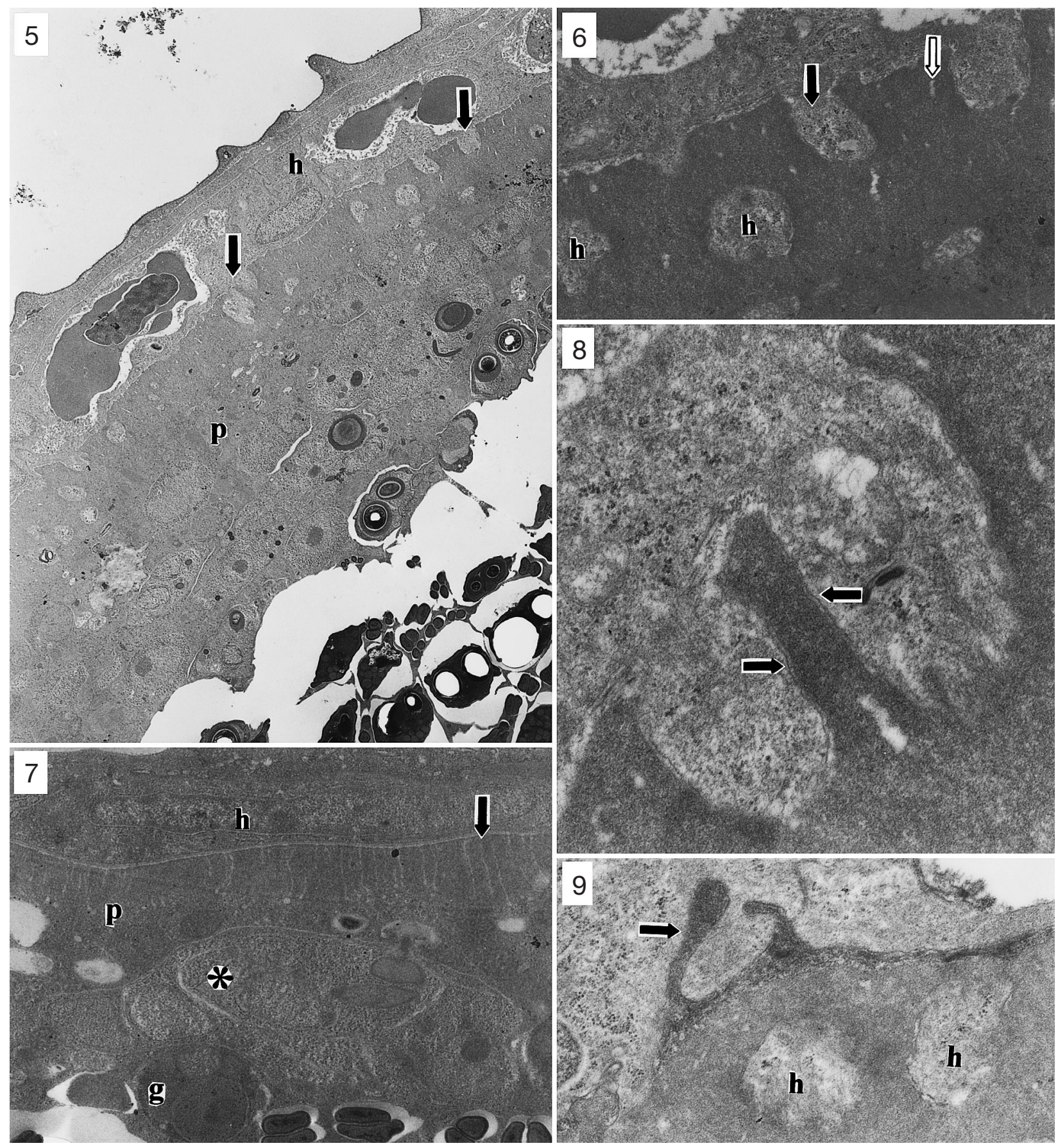

Figs. 5 to 9. Henneguya piaractus infecting Piaracytus mesopotamicus. Electron micrographs of the host-parasite interface. Fig. 5. Direct contact between the plasmodium of $H$. piaractus (p) and the host cells (h). Note the points of phagocytosis (arrows) (×2720). Fig. 6. Amplified portion of Fig. 5 showing pinocytic canals (white arrow) and points of phagocytosis (black arrow) $(\times 9750)$. Fig. 7. Direct contact between the plasmodium $(\mathrm{p})$ and the host cells $(\mathrm{h})$, the presence of numerous pinocytic canals (arrow) and different stages of the life cycle: generative cell $(\mathrm{g})$, and sporogenic stages $(*)(\times 9270)$. Fig. 8. Invaginations of the plasmodium wall. Note the contact between the wall of the host cell and that of the parasite (arrows) $(\times 21560)$. Fig. 9. Expanded view of the plasmodium wall engulfing part of a host cell (arrow) and portions of host cell (h) within the plasmodium $(\times 16000)$

inner zone of the plasmodial wall of Myxobolus sp. (Desser \& Peterson 1978), in association with capsulogenic cells in Sphaerospora dicentrarchi (Sitjà-
Bobadilla \& Alvarez-Pellitero 1992), in generative and sporoplasmic cells of Sphaerospora testicularis (SitjàBobadilla \& Alvarez-Pellitero 1993), in sporoplasmic 


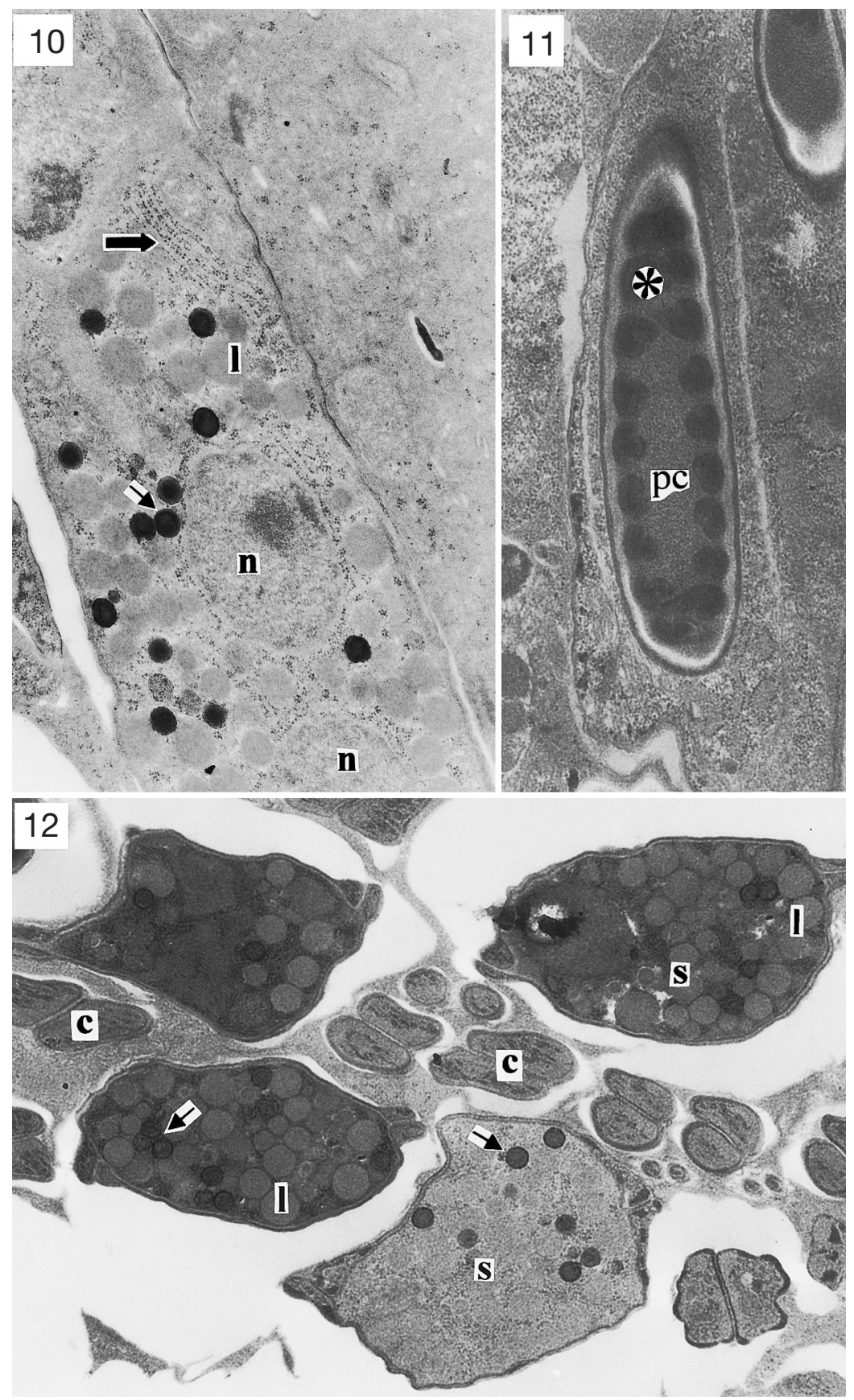

Figs. 10 to 12. Henneguya piaractus. Electron micrographs of spores. Fig. 10. Longitudinal section of the sporoplasm of a young spore showing the 2 nuclei (n), sporoplasmosomes (thin arrow), ribosomes and rough endoplasmic reticulum (thick arrow), and lipid droplets $(1)(\times 12930)$. Fig. 11. Longitudinal section of the polar capsule $(\mathrm{pc})$ with the polar filament $(*) \overline{(\times 15590)}$. Fig. 12. Transversal sections of spores at the level of the sporoplasm (s) and of the caudal process (c). Note the few dark sporoplasmosomes (thin arrows) and numerous lipid droplets (l) $(\times 10300)$

cells of Myxidium gadi (Feist 1995), and in generative cells and developing spores of Enteromyxum scophthalmi (Palenzuela et al. 2002, Redondo et al. 2003), but have not been previously reported for the genus Henneguya. Although these inclusions may serve as energy reserves (Sitjà-Bobadilla \& AlvarezPellitero 1993, Redondo et al. 2003), their true functional and metabolic significance remains to be established (Redondo et al. 2003).

The plasmodial wall of Henneguya piaractus consisted of a single membrane, as in other myxosporean species (Current \& Janovy 1978, Current 1979, Hallett \& Diamant 2001, Dohole et al. 2002), and contained pinocytic canals that extended into the plasmodial ectoplasm, as also seen in several other Henneguya species (Current \& Janovy 1976, 1978, Current 1979, Rocha et al. 1992, Hallett \& Diamant 2001, Azevedo \& Matos 2002, 2003, El-Mansy \& Bashtar 2002). However, there was no coat, nor was the wall surrounded by a capsule of collagen fibres.

A similar organization of the plasmodial surface has been described in Henneguya listerine (Hallett \& Diamant 2001) and for the interlamellar plasmodia of Henneguya exilis (Current \& Janovy 1976). In $H$. exilis, regions of the plasmodial surface are in direct contact with the host cells, with the cytoplasm of the host cell appearing to pass into pinocytic canals of the plasmodial wall (Current \& Janovy 1976). In $H$. listerine, the pinocytic canals of the plasmodial wall function as a nutrient transport system (Hallett \& Diamant 2001), and in Henneguya suprabranchiae these canals supply various developing stages with the nutrients necessary for growth (ElMansy \& Bashtar 2002).

In addition to pinocytic canals, the plasmodial wall of Henneguya piaractus also contained several points of phagocytosis that engulfed parts of the host cells. Thus, this species can obtain nutrients by pinocytosis and phagocytosis. The latter means of obtaining nutrients has been reported in other myxosporeans. Phagocytosis followed by intracellular digestion within a food vacuole was observed in Kudoa quadratum (Uspenskaya 1982). The phagocytosis of chondrocytes was observed in Myxobolus cerebralis, and extrasporo- 


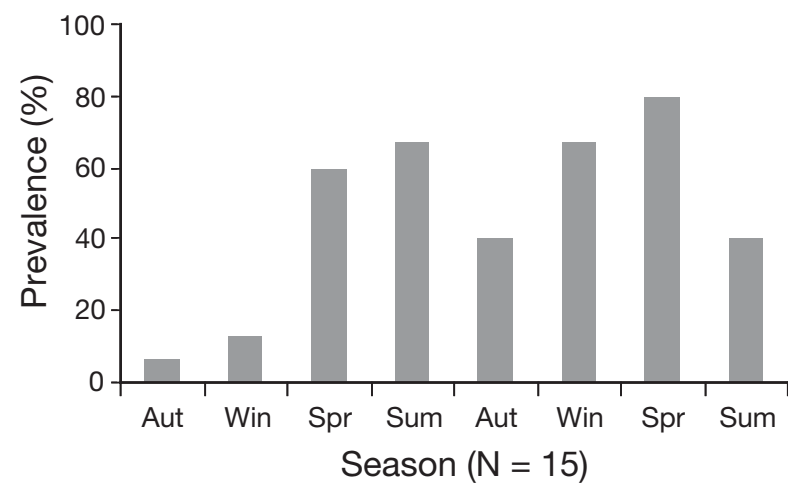

Fig. 13. Henneguya piaractus infecting Piaractus mesopotamicus. Prevalence of $H$. piaractus in relation to seasons. Aut: autumn; Win: winter; Spr: spring; Sum: summer

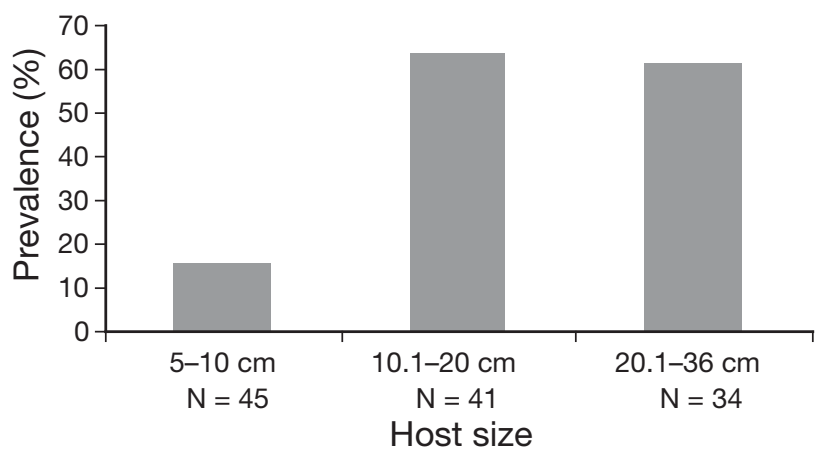

Fig. 14. Henneguya piaractus infecting Piaractus mesopotamicus. Prevalence of $H$. piaractus in relation to host size

gonic stages of some Sphaerospora are known to phagocytise erythrocytes (Lom \& Dyková 1995).

Various species of Henneguya that parasitise gills are reported to be important pathogens, including $H$. exilis in the channel catfish (Current \& Janovy 1976), H. psorospermica in Perca fluviatis (Dyková \& Lom 1978), H. waltairensis in Channa punctatus (Kalavati \& Narasimhamurti 1985), H. creplini in Stizostedion lucioperca (Molnár 1998), H. curvata in Serrasalmus spilopleura (Barassa et al. 2003a) and H. chydadea in Astyanax altiparanae (Barassa et al. 2003b).

Henneguya piaractus causes important pathological alterations in the gills of cultivated pacu (Martins et al. 1997), including haemorrhage and severe inflammatory foci in the gill epithelium. Two layers of elongated, fibroblast-like cells and an inflammatory mononuclear infiltrate surround the parasite. Infected fish generally remain near the pond banks or congregate near inflowing water. Feeding activity decreases over time and the fish become lethargic and swim erratically, with an apparent loss of equilibrium before eventually dying (Martins et al. 1997). As shown here, in advanced stages of infection, the plasmodium occu- pied the entire gill lamella and caused marked dilatation and discreet epithelial hyperplasia. The extensive dilatation of the infected lamellae pushed the neighbouring lamellae sideways and caused deformation and, eventually, fusion. In a massive infection, these alterations may partially compromise the gill functions by reducing the epithelial area and by compressing the blood capillaries. These effects corroborate the potential pathogenicity of $H$. piaractus reported by Martins et al. (1997).

Acknowledgements. The authors thank Dr. Paulo S. Ceccarelli (CEPTA/IBAMA) for assistance during this work and Dr. Stephen Hyslop for editing the English of the manuscript. This work is part of a doctoral thesis by E.A.A. and was supported by CAPES.

\section{LITERATURE CITED}

Adriano EA, Arana S, Ceccarelli PS, Cordeiro NS (2002) Light and scanning electron microscopy of Myxobolus porofilus sp. n. (Myxosporea: Myxobolidae) infecting the visceral cavity of Prochilodus lineatus (Pisces: Characiformes; Prochilodontidae) cultivated in Brazil. Folia Parasitol 49: 259-262

Azevedo C, Matos E (2002) Fine structure of the myxosporean, Henneguya curimata n. sp., parasite of the Amazonian fish, Curimata inormata (Teleostei, Curimatidae). J Eukaryot Microbiol 49:197-200

Azevedo C, Matos E (2003) Fine structure of Henneguya pilosa n. sp. (Myxozoa: Myxosporea), parasite of Serrasalmus altuvei (Characidae) in Brazil. Folia Parasitol 50: $37-42$

Barassa B, Adriano EA, Arana S, Cordeiro NC (2003a) Henneguya curvata sp. n. (Myxosporea: Myxobolidae) parasitising the gills of Serrasalmus spilopleura (Characidae: Serrasalminae), a South American freshwater fish. Folia Parasitol 50:151-153

Barassa B, Arana S, Cordeiro NC (2003b) A new species of Henneguya, a gill parasite of Astyanax altiparanae (Pisces: characidae) from Brazil, with comments on histopathology and seasonality. Mem Inst Oswaldo Cruz 98:761-765

Current WL (1979) Henneguya adiposa Minchew (Myxosporida) in the channel catfish: ultrastructure of the plasmodium wall and sporogenesis. J Protozool 26:209-217

Current WL, Janovy J Jr (1976) Ultrastructure of interlamellar Henneguya exilis in the channel catfish. J Parasitol 62: 975-981

Current WL, Janovy J Jr (1978) Comparative study of ultrastructure of interlamellar and intralamellar types of Henneguya exilis Kudo from channel catfish. J Protozool 25: $56-65$

Desser SS, Peterson WB (1978) Ultrastructural and cytochemical observations on sporogenesis of Myxobolus sp. (Myxosporida: Myxobolidae) from the common shiner Notropis cornutus. J Protozool 25:314-326

Dohole A, Schmahl G, Reather W, Schmidt H, Ritter G (2002) Effects of orally administered chemotherapeutics (quinine, salinomycin) against Henneguya sp. Thelohán, 1892 (Myxozoa: Myxobolidae), a gill parasite in the tapir fish Gnathonemus petersii Gunther, 1862 (Teleostei). Parasitol Res 88:861-867 
Dyková I, Lom J (1978) Histopathological changes in fish gills infected with myxosporidian parasites of the genus Henneguya. J Fish Biol 12:197-202

El-Mansy A, Bashtar AR (2002) Histopathological and ultrastructural studies of Henneguya suprabranchiae Landsberg, 1987 (Myxosporea: Myxobolidae) parasitizing the suprabranchial organ of the freshwater catfish Clarias gariepinus Burchell, 1822 in Egypt. Parasitol Res 88:617-626

Feist SW (1995) Ultrastructural aspects of Myxidium gadi (Georgévitch, 1916) (Myxozoa: Myxosporea) infections in pollack (Pollachius pollachius L.) and saithe ( $P$. virens L.). Eur J Protistol 31:309-317

Hallett SL, Diamant A (2001) Ultrastructure and small-subunit ribosomal DNA sequence of Henneguya lesteri n. sp. (Myxosporea), a parasite of sand whiting Sillago analis (Sillaginidae) from the coast of Queensland, Australia. Dis Aquat Org 46:197-212

Hernandez AR (1989) Cultivo de Colossoma. Primeira Reunion del Grupo de Trabajo Técnico. Guadalupe, Bogotá

Kalavati C, Narasimhamurti CC (1985) Histopathological changes in the gills of Channa punctatus BL. infected with Henneguya waltairensis. Arch Protistenkd 129:199-202

Lom J, Dyková I (1995) Myxosporea (Phylum Myxozoa). In: Woo PTK (ed) Fish diseases and disorders, Vol 1. Protozoan and metazoan infections. CAB International, Wallingford, p 97-148

Martins ML, Souza VN (1997) Henneguya piaractus n. sp. (Myxozoa: Myxobolidae), a gill parasite of Piaractus mesopotamicus Holmberg, 1887 (Osteichthyes: Characidae), in Brazil. Rev Bras Biol 57:239-245

Martins ML, Souza VN, Moraes ER, Moraes JRE, Costa AJ, Rocha UE (1997) Pathology and behavioural effects associated with Henneguya sp. (Myxozoa: Myxobolidae) infections of captive pacu Piaractus mesopotamicus in Brazil. J World Aquacult Soc 28:297-300

Martins ML, Souza VN, Moraes JRE, Moraes FR, Costa AJ (1999) Comparative study of the susceptibility of cultivated fishes to the natural infection with myxosporean

Editorial responsibility: Wolfgang Körting,

Hannover, Germany parasites and tissue changes in the host. Rev Bras Biol 59: 263-269

Mitchell LG (1988) Myxobolid parasites (Myxozoa: Myxobolodidae) infecting fishes of western Montana, with notes on histopathology, seasonality, and intraspecific variation. Can J Zool 67:1915-1922

Molnár K (1998) Taxonomic problems, seasonality and histopathology of Henneguya creplini (Myxosporea) infection of the pikeperch Stizoztedion lucioperca in Lake Balaton. Folia Parasitol 45:261-269

Palenzuela O, Redondo MJ, Alvarez-Pellitero P (2002) Descriptions of Enteromyxum scophtalmi gen. nov., sp. nov. (Myxozoa), an intestinal parasite of turbot (Scophthalmus maximus L.) using morphological and ribosomal RNA sequence data. Parasitology 124:369-379

Redondo MJ, Quiroga MI, Palenzuela O, Nieto JM, AlvarezPellitero P (2003) Ultrastructural studies on the development of Enteromyxum scophthalmi (Myxozoa), an enteric parasite of turbot (Scophthalmus maximus L.). Parasitol Res 90:193-202

Rocha E, Matos E, Azevedo C (1992) Henneguya amazonica n. sp. (Myxozoa, Myxobolidae), parasitizing the gills of Crenicichla lepidota Heckel, 1840 (Teleostei, Cichlidae) from the Amazon river. Eur J Protistol 28:273-278

Sitjà-Bobadilla A, Alvarez-Pellitero P (1992) Light and electron microscopic description of Sphaerospora dicentrarchin. sp. (Myxosporea: Sphaerosporidae) from wild and cultured sea bass, Dicentrarchus labrax L. J Protozool 39:273-281

Sitjà-Bobadilla A, Alvarez-Pellitero P (1993) Ultrastructural and cytochemical observations on the sporogenesis of Sphaerospora testicularis (Protozoa: Myxosporea) from Mediterranean sea bass, Dicentrarchus labrax (L.). Eur J Protistol 29:219-229

Uspenskaya AV (1982) New data on the life cycle and biology of myxosporida. Arch Protistenkd 126:309-338

Vita P, Corral L, Matos E, Azevedo C (2003) Ultrastructural aspects of the myxosporean Henneguya astyanax n. sp. (Myxozoa: Myxobolidae), a parasite of the Amazonian teleost Astyanax keithi (Characidae). Dis Aquat Org 53:55-60

Submitted: June 9, 2004; Accepted: October 4, 2004

Proofs received from author(s): May 9, 2005 